\title{
Investigation of energetic and exergetic performances of parabolic trough collector with using different heat transfer fluids
}

\author{
F.Mertkan Arslan ${ }^{1 *}$ and Hüseyin Günerhan ${ }^{2}$ \\ ${ }^{1}$ Ege University, Graduate School of Natural and Applied Science, 35100 Bornova-Izmir-Turkey \\ ${ }^{2}$ Ege University, Faculty of Engineering, Mechanical Engineering Department, 35100 Bornova-Izmir-Turkey
}

\begin{abstract}
In this study energetic and exergetic performances of parabolic trough collector is theoretically investigated by using 120 l/min synthetic "Dowtherm A" oil , 1200 l/min Air at $100 \mathrm{bar}$ (10 MPa) and 150 $1 / \mathrm{min}$ molten salt which is mixture of $60 \mathrm{wt} \%$ sodium nitrate $(\mathrm{NaNO} 3)$ and $40 \mathrm{wt} \%$ potassium nitrate (KNO3) which are widely used as heat transfer fluids. Fluids performance comparisons were performed with the LS-2 module, which is used with vacuum in annulus and Cermet as a selective coating. LS-2 module has $7.8 \mathrm{~m}$ receiver length and is $39 \mathrm{~m} 2$ aperture area. As a result, the maximum exergy efficiency of the molten salt, synthetic oil, Air to be $41.19 \%$ at $422{ }^{\circ} \mathrm{C}, 40.82 \%$ at $400{ }^{\circ} \mathrm{C}, 40.33 \%$ at $402{ }^{\circ} \mathrm{C}$, respectively. The maximum exergy of air is higher than other working fluids up to $310^{\circ} \mathrm{C}$ but after about $310^{\circ} \mathrm{C}$ the exergy of the molten salt is higher than the others. The molten salt has the best energy efficiency at its operating temperatures $\left(250^{\circ} \mathrm{C}\right.$ to $\left.550^{\circ} \mathrm{C}\right)$ than other working fluids.
\end{abstract}

\section{Introduction}

With the depletion of fossil fuels, solar energy is gaining importance as a sustainable and inexhaustible energy source that does not harm the environment. Parabolic solar technology is the most proven and cost-effective, large-scale solar energy technology among other concentrated solar systems [1].

If a suitable oil ullage system is installed at the factory and the maximum operating temperature is properly operated below the limit specified by the manufacturer, the service life of the existing thermal oils does not exceed 30 years. The presence of a complete thermal oil set with different properties and costs is another advantage of thermal oils and the choice of the best thermal oil for a particular project depends on the operating conditions. Cheap and low-vapor pressurized oils are available for operating temperatures below $350^{\circ} \mathrm{C}$, while more expensive and higher vapor pressure oils, such as Syltherm 800, are available at temperatures up to $420{ }^{\circ} \mathrm{C}$. If oils operating temperature increases from $398^{\circ} \mathrm{C}$ to $420^{\circ} \mathrm{C}$, it causes a significant increase in price. Therefore, modern solar thermal power plants use thermal oils with a working temperature limit of $398{ }^{\circ} \mathrm{C}$. Thermal oils have been used in solar energy fields since the 1970s, due to their low cost, low thermal pressure, good thermal stability and long service life when the operating conditions recommended by the manufacturers are met [2]. Thermal oils have some limitations as they are not environmentally clean, have a high fire risk, the operating temperature should be below $400{ }^{\circ} \mathrm{C}$ and in some cases they can cause degradation of the receiver vacuum due to the production of hydrogen [3]

Parabolic trough collector (PTC), which works with molten salt technology, has attracted attention in recent years due to its high performance and low-cost aspects [4]. Some authors have shown that Levelized Costs of
Electricity (LCOE) is reduced with higher operating temperatures, greater temperature differences, and direct change of the thermal oil system with the molten salt. Furthermore, the molten salts have some advantages over the thermal oil (e.g.low environmental effect). However, A significant problem arises when thermal oil and molten nitrate salts are completely changed, the molten salts exhibit a significantly higher melting point with the risk of freezing and / or filling / drainage of the solar field tubes [5]. Trabelsi et al. [6] simulated the study with using molten salt and Therminol VP 1 in PTC, they showed that when molten salt is used as working fluid, the average energy efficiency increased by $6 \%$ and the LCOE decreased by approximately $20 \%$ compared to Therminol VP-1.

The use of pressurized gases as working fluid is clean and safe, with no temperature limitation and provides a perfect integration with a storage system based on molten salts [3]. In addition, there are some advantages of pressurized air over thermal oils which are higher steam temperature, cheaper thermal storage, no fire hazard, no pollutant. But in other hands, there are some disadvantages which are lower heat transfer coefficient, the complexity of solar field control, higher pressure in solar field piping, higher pumping power [2].

Bellos et al. [7] investigated the energetic and exegetic performance of PTC working fluids which pressurized water, Therminol VP-1, nitrate molten salt, sodium liquid, air, carbon dioxide, and helium. As a results of study liquid fluids have higher performance compared to gas fluids, the liquid sodium is most efficient choice for high-temperature levels up to $1100 \mathrm{~K}$ while the Pressurized water is suitable for lowtemperature levels up to $550 \mathrm{~K}$, carbon dioxide and helium best suited for temperatures higher than $1100 \mathrm{~K}$ and they calculated that maximum exergy performance

* Corresponding author: mertkan.arslan@gmail.com 
for air, carbon dioxide, and helium are $40.12 \%, 42.06 \%$, and $42.21 \%$ respectively.

Many researchers have increased the thermal performance of collectors by using nanofluids as heat transfer fluid. Mwesigye and Mayer [8] conducted the study with using Ag-Therminol VP-1, Cu-Therminol VP-1 and $\mathrm{Al}_{2} \mathrm{O}_{3}$-Therminol VP-1 nanofluids, they have been shown that the thermal efficiency increases by $13.9 \%, 12.5 \%$, and $7.2 \%$, respectively, when the nanofluid volumetric ratio is increased from 0 to $6 \%$. Kaloudis et al. [9] showed that Syltherm $800 / \mathrm{Al}_{2} \mathrm{O}_{3}$ nanofluid at the concentration $4 \%$ increased the collector efficiency by $10 \%$ with using the two-phase method.

Concentrating solar power can be easily combined with thermal fuel storage (TES) and conventional fuels, so it has a distinct feature among other renewable energy generation sources, in addition, TES systems generally have lower capital costs than other storage technologies. TES systems have high operating efficiencies as well as low capital costs compared to other storage technologies [10].

\section{Model description}

\subsection{Fluids properties}

In order to be able to make a proper comparison of working fluids within the study, the volumetric flow rates of working fluids were selected carefully and appropriately. The selections were made by taking into account the change of thermal and exergy efficiencies with the volumetric flow rate of fluids. Volumetric flow rate of synthetic oil, molten salt, and air are selected 120 $1 / \mathrm{min}, 150 \mathrm{l} / \mathrm{min}$ and $1200 \mathrm{l} / \mathrm{min}$ respectively.

The thermodynamic properties of Dowtherm A are obtained with [11] depending on the temperature. Dowtherm A decomposes above $673.15 \mathrm{~K}$. Another working fluid is binary mixture of molten salt consisting of $60 \% \mathrm{NaNO}_{3}$ and $40 \% \mathrm{KNO}_{3}$. Maximum working temperature of molten sait is $873 \mathrm{~K}$ and a freezing point is about $493 \mathrm{~K}$. Molten salt is a more economical and environmentally friendly material than the synthetic oil, but the main disadvantage of the molten salt is that due to its high melting point, complex freeze protection in the solar field is required. [12]. Thermophysical properties of molten salt are shown between equation (1) and (4) $[5,13]$

$$
\begin{gathered}
\rho_{f}=2.1060-6.6795 \times 10^{-4} T \\
c_{p, f}=1.5404-3.092 \times 10^{-5} T \\
k_{f}=0.3804+3.452 \times 10^{-4} T \\
\mu_{f}=22.714-0.12 T+2.281 \times 10^{-4} T^{2}-1.474 \times 10^{-7} T^{3}
\end{gathered}
$$

The pressure of air is choosen 100 bar because it is the higher pressure at which the system can be reached without mechanical risk. When the pressure is at 100 bar, the absorber tube and the selective coating temperature limit are up to $550{ }^{\circ} \mathrm{C}$ [14]. Therefore, in this study the maximum operating temperature of air at determined as $550{ }^{\circ} \mathrm{C}$. Thermophysical properties of air at 100 bar is obtained with references [15] and [16].

\subsection{Mathematical model}

Section 2.2 can be divided into two parts which optical model and thermal model.

\subsubsection{Optic model}

The available energy from the sun on the collector aperture area is shown by the eq. (5). Absorbtion of radiation from the sun by the receiver is calculated by the eq. (6). Finally, in the eq. (6) optical efficiency is calculated by eq. (7) and the final reflectance is shown with eq. (8). Parameters of final reflectance are shown with Table 1.

$$
\begin{gathered}
Q_{s}=A_{a} I_{b} \\
Q_{a b s}=Q_{s} \eta_{o p t} \\
\eta_{o p t}=\rho \tau_{c} \alpha_{a b s} \gamma_{c o l} K \\
\rho=\rho_{0} \cdot \rho_{1} \cdot \rho_{2} \cdot \rho_{3} \cdot \rho_{4} \cdot \rho_{5} \cdot p_{6}
\end{gathered}
$$

Table 1. Definition of final reflectance parameters

\begin{tabular}{lc}
\hline Parameters & Symbol \\
\hline Reference reflectance & $\rho_{0}$ \\
Shadow effect & $\rho_{1}$ \\
Twisting error & $\rho_{2}$ \\
Geometric errors & $\rho_{3}$ \\
Mirror clearness & $\rho_{4}$ \\
Receiver clearness & $\rho_{5}$ \\
Possible errors & $\rho_{6}$ \\
\hline
\end{tabular}

Mirror clearness is calculated with by (9) [17].

$$
\rho_{5}=\frac{\rho_{4}+1}{2}
$$

For the LS-2 module, incident angle modifier , $K$, can be calculated with the next correlation [18].

$$
K=\frac{1}{\cos \theta}\left(\cos \theta+0.000884 \theta-0.00005369 \theta^{2}\right)
$$

\subsubsection{Thermal Model}

The thermal model in the parabolic solar collector is developed according to the energy balance in the receiver tube [19].

$$
Q_{a b s}=Q_{\text {loss }}+Q_{\text {useful }}
$$


In the eq. (11), the absorption of the radiation from the sun by the receiving tube is $Q_{a b s}$. The heat losses in the collector is $Q_{\text {loss }}$, and $Q_{\text {gain }}$ represents the useful heat produced in the collector. Due to vacuum in the annulus between of receiver surface and cover inner surface, heat transfer with convection can be negligible [17]. The heat losses within the eq. (11) can be calculated with (12-14) and they are all equal $[8,17,20]$.

$$
\begin{gathered}
Q_{l o s s, p-c}=\frac{\sigma \pi D_{p o} L\left(T_{p o}^{4}-T_{c i}^{4}\right)}{\frac{1}{\varepsilon_{p o}}+\left(\frac{\left(1-\varepsilon_{p o}\right) D_{p o}}{\varepsilon_{p o} D_{c i}}\right)} \\
Q_{l o s s-c}=\frac{2 \pi k_{c} L\left(T_{c i}-T_{c o}\right)}{\ln \left(D_{c o} / D_{c i}\right)} \\
Q_{l o s s, c-a i r}=h_{c-a i r} \pi D_{c o} L\left(T_{c o}-T_{a i r}\right)+\sigma \pi \varepsilon_{c o} D_{c o} L\left(T_{c o}^{4}-T_{s k y}^{4}\right)
\end{gathered}
$$

Emittance of the outer surface of the absorber tube depends on the temperature. In this study, the tube selective coating was selected cermet and its emittance correlation is shown with next equation [19].

$$
\varepsilon_{p o}=2.249 \times 10^{-7} T^{2}+1.039 \times 10^{-4} T+5.599 \times 10^{-2}
$$

In eq. (14) the heat transfer coefficient is given by;

$$
h_{c-a i r}=\frac{k_{c-a i r}}{D_{c o}} N u_{c o}
$$

The heat transfer coefficient in eq. (16) must be calculated with the temperature (T5 - T6)/2. When the collector is operated in windy environment, the heat transfer which between the glass cover and the environment is by forced convection. In eq. (16) Nusselt number is calculated by;

$$
N u_{D c o}=C \operatorname{Re}_{\text {air }}^{m} \operatorname{Pr}_{\text {air }}^{n}\left(\frac{\operatorname{Pr}_{\text {air }}}{\operatorname{Pr}_{c o}}\right)^{1 / 4}
$$

$P r_{a i r}$ and $P r_{c o}$ are calculated according to $\mathrm{T}_{\text {air }}$ and $\mathrm{T}_{\mathrm{co}}$, respectively. If the condition $0.7<P r_{\text {air }}<500$ and 1 $<R e_{D c d}<106$ is provided, (17) is considered valid. $\mathrm{C}$ and $\mathrm{m}$ constants can be calculated with Table 2. depending on the Reynold number [19].

Table 2. Reynold numarasına göre $C$ ve $m$ sabitleri değerleri

\begin{tabular}{lcc}
\hline $\boldsymbol{R e}_{\boldsymbol{D c o}}$ & $\boldsymbol{C}$ & $\boldsymbol{m}$ \\
\hline $1-40$ & 0,75 & 0,4 \\
$40-1000$ & 0,51 & 0,5 \\
$1000-200000$ & 0,26 & 0,6 \\
$200000-1000000$ & 0,076 & 0,7 \\
\hline
\end{tabular}

The Nusselt number can also be calculated by the different approach given by [17].

$$
N u_{D c o}=0.193 \operatorname{Re}_{\text {air }}^{0.618} \operatorname{Pr}_{\text {air }}^{0.33}
$$

The sky temperature can be considered as approximately 8 degrees lower than the air temperature [21].

$$
T_{s k y}=T_{a i r}-8
$$

The useful heat in the receiver pipe can be calculated with using equations $(20-22)[8,17]$.

$$
\begin{gathered}
Q_{\text {useful }}=\dot{m} c_{p}\left(T_{\text {outlet }}-T_{\text {inlet }}\right) \\
Q_{u \text { seful }}=Q_{a b s}-A_{a} U_{L}\left(T_{p o}-T_{\text {air }}\right) \\
Q_{\text {useful }}=\pi D_{p i} L_{f}\left(T_{p i}-T_{f}\right)
\end{gathered}
$$

The loss coefficient can be calculated by the following formula [20];

$$
U_{L}=\frac{Q_{\text {loss }}}{A_{p o}\left(T_{p o}-T_{\text {air }}\right)}
$$

The average temperature inside the pipe is calculated by [17] ;

$$
T_{f}=\frac{\left(T_{\text {inlet }}+T_{\text {outlet }}\right)}{2}
$$

In the receiver pipe convection heat transfer coefficient can be calculated by eq. (25) and The Nusselt number of the fluid is calculated based on inside diameter of the receiver pipe [21].

$$
h_{f}=\frac{N u_{f} k_{f}}{D_{p i}}
$$

If the Reynold number is $R e<2300$, the flow type in the receiver pipe is laminar flow. In the PTC, for the laminar flow, the Nusselt number is assumed to be constant and the value is equal to 4.36 [21]. If $\operatorname{Re}>2300$, turbulent flow occurs and the Nusselt number is calculated by next eq. (26).

$$
N u_{f}=\frac{f_{p} / 8\left(\operatorname{Re}_{f}-1000\right) \operatorname{Pr}_{f}}{1+12.7 \sqrt{f_{p} / 8}\left(\operatorname{Pr}_{f}^{2 / 3}-1\right)}
$$

Eq. (26) is valid within the conditions of $0.5<P r_{a k}<2000$ and $2000<R e_{a k}<5 \times 10^{6}$ [22]. The Nusselt number can also be calculated using another approach which is showed with next equation.

$$
N u_{f}=0.023 \operatorname{Re}_{f}^{0.8} \operatorname{Pr}_{f}^{0.4}
$$

The Reynolds number of the flowing fluid in the receiving pipe is calculated by the eq. (28) and the Prandtl number by the equation (29). 


$$
\begin{aligned}
& \operatorname{Re}_{f}=\frac{4 \dot{m}}{\pi D_{p i} \mu_{f}} \\
& \operatorname{Pr}_{f}=\frac{\mu_{f} c_{p, f}}{k_{f}}
\end{aligned}
$$

The pressure drop and for the turbulant flow friction factor in the tube are given by equations (30) and (31) [17].

$$
\begin{gathered}
\Delta P=f_{p} \frac{L}{D_{p i}}\left(\frac{1}{2} \rho_{f} u_{f}^{2}\right) \\
f_{p}=\frac{1}{\left(0.79 \ln \left(\mathrm{Re}_{a k}\right)-1.64\right)^{2}}
\end{gathered}
$$

The average temperature drop between the receiver pipe and the fluid can be calculated with the formula (32) [20].

$$
\bar{T}_{p o}-\bar{T}_{f}=Q_{u s e f u l}\left[\frac{1}{\pi D_{p i} L h_{f}}+\frac{\ln \left(D_{p o} / D_{p i}\right)}{2 \pi k_{p} L}\right]
$$

The thermal efficiency of the collector is shown by the next formula [8].

$$
\eta_{t h}=\frac{Q_{u s e f u l}}{I_{b} A_{a}}=\frac{Q_{\text {useful }}}{Q_{s}}
$$

\subsubsection{Exergy Model}

Loss of the available energy due to the creation of entropy in irreversible systems is defined as exergy [23]. Two types of second law analysis are used. First, the method of entropy production from irreversible processes and the second is using the consept of exergy. Since entropy production is closely related to exergy disappearance, both approaches are equivalent [24]. If the exergy balance is applied to the solar collectors, the exergy balance can be expressed;

$$
\dot{E} x_{\text {inlet }}-\dot{E} x_{\text {outlet }}-\dot{E} x_{\text {loss }}-\dot{E} x_{\text {change }}-\dot{E} x_{\text {destroy }}=0
$$

The exergy accumulated by the fluid flow from the receiver is equal to the rate of gained exergy. Its showed by eq. (35) [25].

$$
\dot{E} x_{\text {gain }}=\dot{E} x_{\text {outlet }}-\dot{E} x_{\text {inlet }}=\dot{m} c_{p}\left(T_{\text {outlet }}-T_{\text {inlet }}-T_{\text {air }} \ln \frac{T_{\text {outlet }}}{T_{\text {inlet }}}\right)+\frac{\dot{m} \Delta P}{\rho_{f}}
$$

The sun is considered an endless source and the temperature of sun is $\mathrm{T}_{\text {sun }}=5762^{\circ} \mathrm{C}$. Exergy amount of solar radiation absorbed by the collector receiver is expressed by eq.(36) [26].

$$
\dot{E} x_{\text {inlet }, \text { sun }}=Q_{s}\left[1+\frac{1}{3}\left(\frac{T_{\text {air }}}{T_{\text {sun }}}\right)^{4}-\frac{4 T_{\text {air }}}{3 T_{\text {sun }}}\right]
$$

The amount of total loss exergy for a solar collector is showed with eq. (37). Exergy loss by optical errors and heat transfer from the receiver to the environment is can be calculated respectively with equations (38) and (39) [17].

$$
\begin{gathered}
\dot{E} x_{\text {loss }}=\dot{E} x_{\text {loss }, \text { opt }}+\dot{E} x_{\text {loss }, \text { th }} \\
\dot{E} x_{\text {loss }, \text { opt }}=\left(1-\eta_{\text {optic }}\right) \dot{E} x_{\text {inlet }, \text { sun }} \\
\dot{E} x_{\text {loss }, \text { th }}=Q_{\text {loss }}\left(1-\frac{T_{\text {air }}}{T_{p o}}\right)
\end{gathered}
$$

Exergy destruction of the system is defined as irreversibility. The total irreversibility in the solar collector can be expressed by next formula [27].

$$
\dot{E} x_{\text {destroy }}=\dot{E} x_{d e s t r o y, \Delta P}+\dot{E} x_{d e s t r o y, p o-s u n}+\dot{E} x_{d e s t r o y, p o-f}
$$

In a solar collector system, exergy is destroyed due to the friction and heat transfer processes of the fluid. If there is a friction flow in the receiving tube, a pressure drop between the inlet and outlet of the receiver causes the generation of entropy and its shown given eq. (41) [25].

$$
\dot{E} x_{\text {destroy }, \Delta P}=T_{\text {air }} \frac{\dot{m} c_{p} \Delta P}{\rho_{f}} \frac{\ln \left(\frac{T_{\text {outlet }}}{T_{\text {inlet }}}\right)}{T_{\text {outlet }}-T_{\text {inlet }}}
$$

Exergy destruction which is from the sun to the receiver during solar energy absorption in the receiver is calculated given by eq. (42) [17].

$$
\dot{E} x_{d e s t r o y, p o-s u n}=\eta_{o p t} \dot{E} x_{i n l e t, s u n}-Q_{a b s}\left(1-\frac{T_{a i r}}{T_{p o}}\right)
$$

Eq. (43) is used for the calculation of the amount of exergy destruction caused by the temperature difference between the working fluid temperature and the receiver tube wall.

$$
\dot{E} x_{\text {destroy,po-f }}=\dot{m} c_{p} T_{\text {air }}\left(\ln \frac{T_{\text {outlet }}}{T_{\text {inlet }}}-\frac{T_{\text {outlet }}-T_{\text {inlet }}}{T_{p o}}\right)
$$

Exergy efficiency is the rate of the gain exergy and amount of exergy which is obtained from the sun. Exergy efficiency is expressed with eq. (44) and The amount of Ex change for the steady state is zero [25]. 


$$
\eta_{\text {ex }}=\frac{\dot{E} x_{\text {gain }}}{\dot{E} x_{\text {inlet, sun }}}=1-\frac{\dot{E} x_{\text {loss }}-\dot{E} x_{\text {change }}-\dot{E} x_{\text {destroy }}}{\dot{E} x_{\text {inlet }, \text { sun }}}
$$

\subsection{Model validation}

In this study, the LS-2 collector was used which is tested in the Sandia National Laboratory. Collector heat collection equipment lenght is $7.8 \mathrm{~m}$ and collector area is $39 \mathrm{~m}^{2}$. Table 3. shows all the geometrical and optical properties of the LS-2 collector [17,18]. The annular which between the receiving pipe and the glass tube is vacuumed. Syltherm 800 was used as working fluid in LS-2 collector. Reference [28] is used for all thermodynamic properties of the Syltherm 800. The selective coating type is carmet and its the emisity can be found with eq. (15).

Table 3. Geometric and optic properties of LS-2 collector

Geometric Properties

\begin{tabular}{lccc}
\hline Parameter & Symbol & Value & Unit \\
Width & $W$ & 5 & $\mathrm{~m}$ \\
Lenght & $L$ & 7,8 & $\mathrm{~m}$ \\
Aparture area & $A_{a}$ & 39 & $\mathrm{~m}^{2}$ \\
Receiver inner diameter & $D_{p i}$ & 0,066 & $\mathrm{~m}$ \\
Receiver outer diameter & $D_{p o}$ & 0,07 & $\mathrm{~m}$ \\
Cover inner diameter & $D_{c i}$ & 0,109 & $\mathrm{~m}$ \\
Cover outer diameter & $D_{c o}$ & 0,115 & $\mathrm{~m}$ \\
Optic Properties & & & \\
\hline Absorber absorbance & $\alpha_{p}$ & 0,96 & - \\
intercept factor & $\gamma$ & 1 & - \\
Cover transmittance & $\tau_{c}$ & 0,95 & - \\
Collector reflectance & $\rho_{0}$ & 0,935 & - \\
Receiver shadowing & $\rho_{1}$ & 0,974 & - \\
Tracking error & $\rho_{2}$ & 0,994 & - \\
Geometry accuracy & $\rho_{3}$ & 0,98 & - \\
Mirror clearness & $\rho_{4}$ & 0,98 & - \\
Receiver clearness & $\rho_{5}$ & 0,99 & - \\
Miscellaneous factors & $\rho_{6}$ & 0,96 & - \\
Thermal conductivies & & & \\
\hline Absorber thermal conductivity & $k_{p}$ & 54 & $\mathrm{~W} / \mathrm{mK}$ \\
Cover thermal conductivity & $k_{c}$ & 0,78 & $\mathrm{~W} / \mathrm{mK}$
\end{tabular}

Table 4. shows data of tested LS2-2 of incident beam, wind speed, air temperature, inlet temperature of HTF and volumetric flow rates of the fluid. In addition, output temperatures of working fluid and the thermal efficiency are shown in the table [18,29].
Table 4. Reynold numarasına göre $C$ ve $m$ sabitleri değerleri

\begin{tabular}{cccccccc} 
& $\begin{array}{c}\text { Incident } \\
\text { beam }\end{array}$ & $\begin{array}{c}\text { Wind } \\
\text { speed }\end{array}$ & $\boldsymbol{T}_{\text {air }}$ & $\begin{array}{c}\text { Flow } \\
\text { rate }\end{array}$ & $\boldsymbol{T}_{\text {input }}$ & $\boldsymbol{T}_{\text {input }}$ & $\boldsymbol{\eta}_{\text {th }}$ \\
\hline No. & $(\mathrm{W} / \mathrm{m} 2)$ & $(\mathrm{m} / \mathrm{s})$ & $\left({ }^{\circ} \mathrm{C}\right)$ & $(\mathrm{Lt} / \mathrm{min})$ & $\left({ }^{\circ} \mathrm{C}\right)$ & $\left({ }^{\circ} \mathrm{C}\right)$ & $(\%)$ \\
\hline 1 & 933,7 & 2,6 & 21,2 & 47,7 & 102,2 & 124 & 72,51 \\
2 & 968,2 & 3,7 & 22,4 & 47,8 & 151 & 173,3 & 70,9 \\
3 & 982,3 & 2,5 & 24,3 & 49,1 & 197,5 & 219,5 & 70,17 \\
4 & 909,5 & 3,3 & 26,2 & 54,7 & 250,7 & 269,4 & 70,25 \\
5 & 937 & 1,0 & 28,8 & 55,5 & 297,8 & 316,9 & 67,98 \\
6 & 880,6 & 2,9 & 27,5 & 55,6 & 299 & 317,2 & 68,92 \\
7 & 903,2 & 4,2 & 31,1 & 56,3 & 355,9 & 374 & 63,82 \\
8 & 920,9 & 2,6 & 29,5 & 56,8 & 379,5 & 398 & 62,34 \\
\hline
\end{tabular}

For validation, the test model and the calculation model was compared. As a result of the validation, max. and min. thermal efficiency deviations are $0.56 \%$ and $3.25 \%$, respectively and max and min output temperature deviations are $0.16 \%$ and $0.023 \%$, respectively. Comparison of model and test results is shown in fig. 1 .

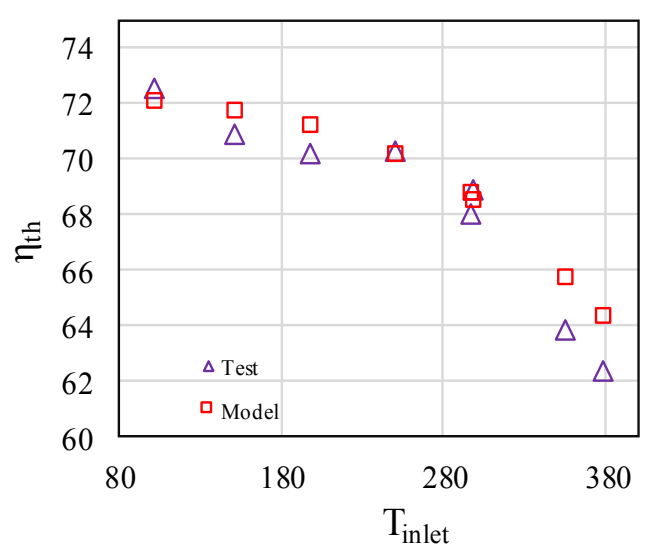

Fig. 1 Comparison of model and test results

\section{Results}

\subsection{The examined model}

For comparison of working fluids, in the examined model $1201 /$ min Dowtherm A, $12001 / \mathrm{min}$ Air at 100 bar (10 MPa) and $1501 /$ min molten salt which contains $40 \mathrm{wt} \%$ and potassium nitrate (KNO3) are used. Section 2.1 shows the properties of fluids. In the examined model, direct radiation $900 \mathrm{~W} / \mathrm{m}^{2}$, wind speed $2 \mathrm{~m} / \mathrm{s}$, air temperature $20 \mathrm{C}$ are selected. By selecting air temperature, sky temperature can be calculated using the equation (19). 


\subsection{Energetic and exergetic investigation}

In this section using with parameters of examined model, the working fluids are analyzed and compared in terms of energy and exergy. Fig 2. shows the energy efficiencies according to the inlet temperatures for all three working fluid range from $20^{\circ} \mathrm{C}$ and $550{ }^{\circ} \mathrm{C}$. Liquid working fluids synthetic oil and molten salt, provide better energy performance than gas fluid which is air at 100 bar. However, although the air at 100 bar is a gas fluid, its thermal efficiency is quite close to liquid fluids. Fig 2. And fig 3. provides that molten salt has better energy performance than air and synthetic oil at its operating temperatures. Fig 3 . is used to better visualize the efficiency relationship between synthetic oil and molten salt. The efficiency of the molten salt and the synthetic oil at $250{ }^{\circ} \mathrm{C}$ is 71.67 and 71.55 , respectively. Fig 4 shows the comparison of the heat transfer coefficient of all fluids with respect to the fluid temperature. The heat transfer coefficient of molten salt is quite high compared to the air and synthetic oil.

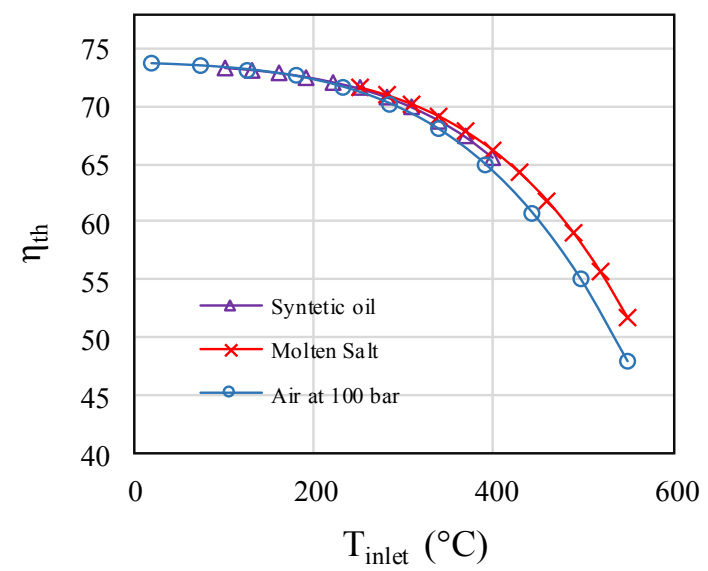

Fig. 2 Energy efficiencies of working fluids according to the inlet temperatures $20^{\circ} \mathrm{C}$ to $550^{\circ} \mathrm{C}$

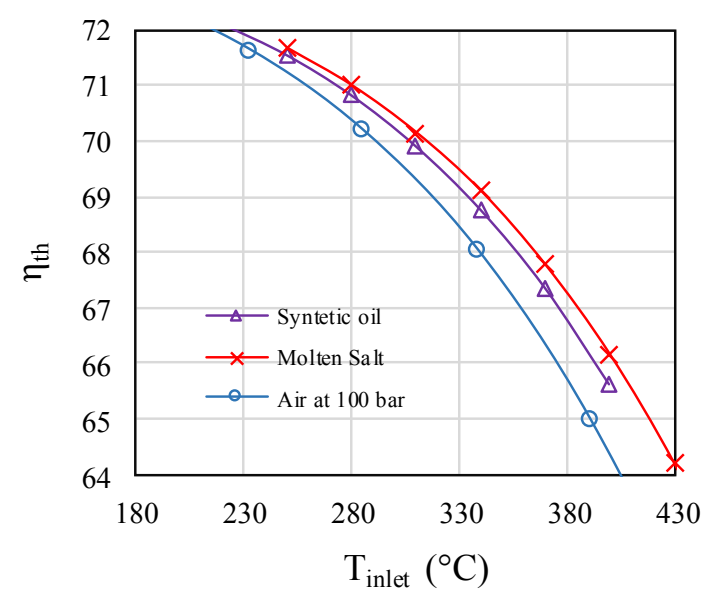

Fig. 3 Energy efficiencies of working fluids according to the inlet temperatures $200{ }^{\circ} \mathrm{C}$ to $430{ }^{\circ} \mathrm{C}$

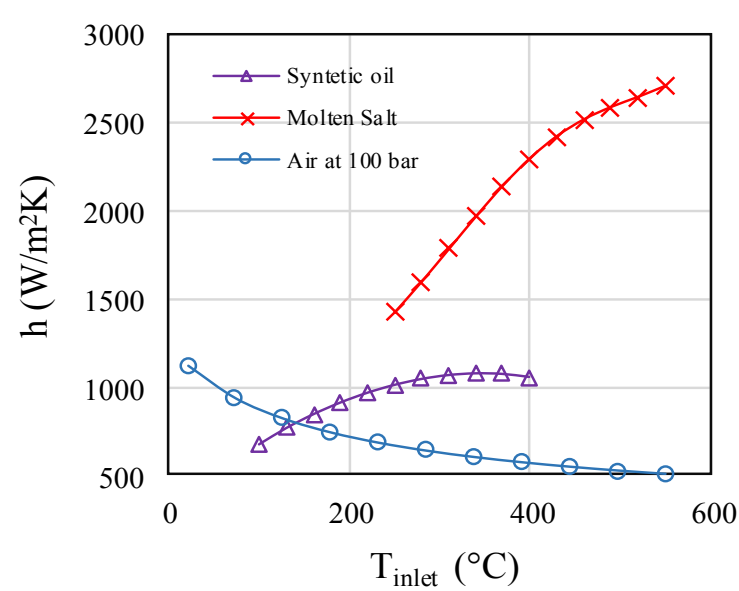

Fig. 4 heat transfer coefficient of working fluids according to the inlet temperatures

The exergy efficiencies of working fluids is shown with fig 5. Exergy efficiencies of synthetic oil, molten salt, and air at 100 bar are very close to each other. As we can see at fig 6. exergy efficiency of air up to $310{ }^{\circ} \mathrm{C}$ is higher than other fluids, but after this temperature, the exergy efficiency of air remains low than others.

After $300{ }^{\circ} \mathrm{C}$ the exergy performance of the molten salt is slightly better than syntetic oil because the molten salt can operate at higher temperatures than the synthetic oil. The maximum efficiency of the molten salt is $41.19 \%$ at $422{ }^{\circ} \mathrm{C}$ while the maximum exergy efficiency of the syntetic oil is $40.82 \%$ at $400{ }^{\circ} \mathrm{C}$ at its maximum working temperature. The maximum exergy efficiency of the air is slightly lower than liquid fluids and the value is $40.33 \%$ at $402{ }^{\circ} \mathrm{C}$.

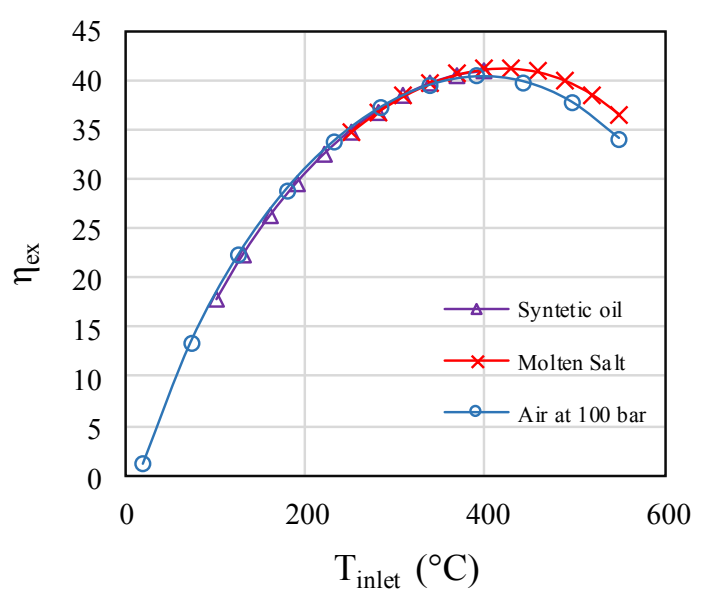

Fig. 5 Exergy efficiencies of working fluids according to the inlet temperatures $20{ }^{\circ} \mathrm{C}$ to $550{ }^{\circ} \mathrm{C}$ 


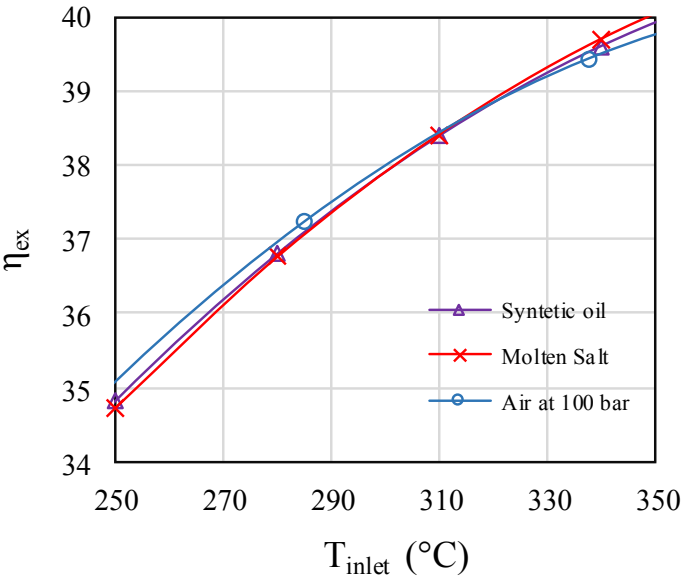

Fig. 6 Exergy efficiencies of working fluids according to the inlet temperatures $250{ }^{\circ} \mathrm{C}$ to $350{ }^{\circ} \mathrm{C}$

Fig 7. shows the pressure drop according to the tube length of the working fluids at $300{ }^{\circ} \mathrm{C}$, and fig 8 . shows the pressure drop with respect to the fluid temperature. The pressure drop depends on the fluid velocity, density, and viscosity of the working fluid. However, the pressure drop is significantly dependent on the fluid velocity and density rather than the viscosity. Although the density of the air is low its fluid velocity is higher than the other fluids (because of the volumetric flow rate of air $1200 \mathrm{l} / \mathrm{min}$ and for molten salt is $150 \mathrm{l} / \mathrm{min}$ were selected in this study). Conversely, the molten oil has a high density than air but its fluid velocity is lower than air. Thus, as shown in fig. 7, The pressure drops of air and molten salt are almost equal.

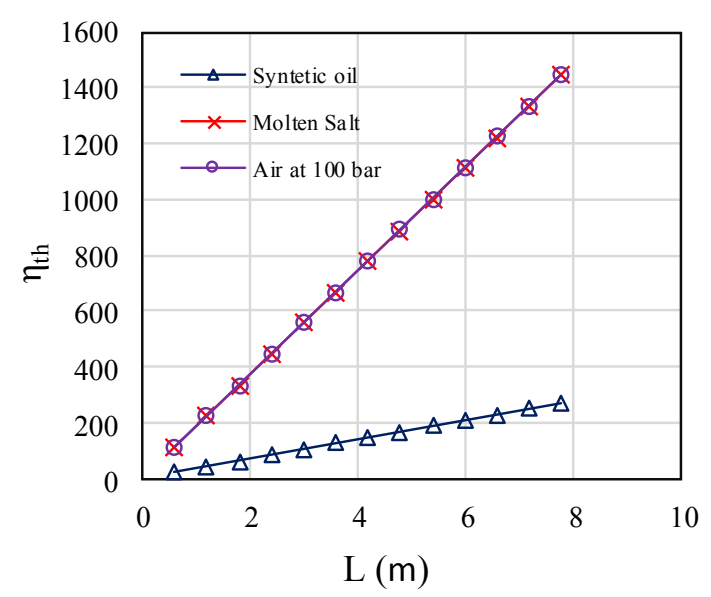

Fig. 7 Pressure drop according to receiver length

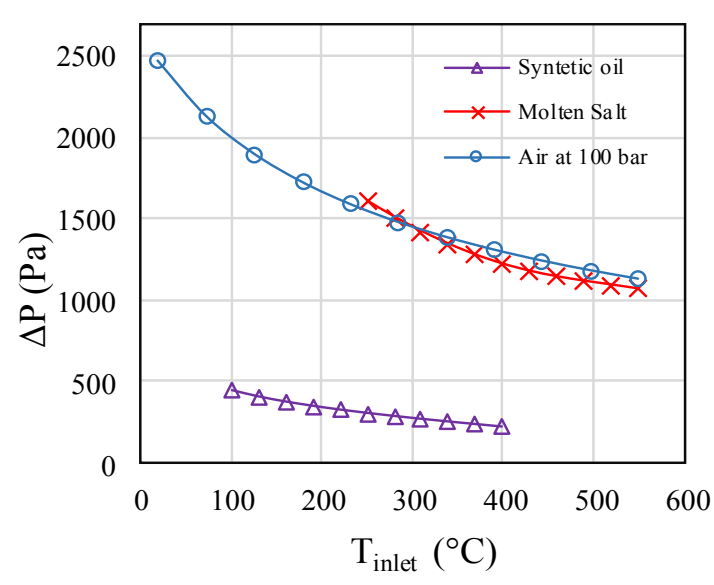

Fig. 8 Pressure drop according to fluids inlet temperature

\section{Conclusions}

In the LS-2 collector, $120 \mathrm{l} / \mathrm{min}$ Dowtherm A, 1200 1/min Air at $100 \mathrm{bar}$ and $150 \mathrm{l} / \mathrm{min}$ molten salt which is mixture of $60 \mathrm{wt} \% \mathrm{NaNO}_{3}$ and $40 \mathrm{wt} \% \mathrm{KNO}_{3}$ are compared in terms of energetic and exergetic performances. As a result, working fluids of comparisons in the scope of the study, energy and exergy performance of high-pressure air (100 bar) is quite close to synthetic oil and molten salt (see fig. 2 and fig. 4). The energy performance of the molten salt is found to be higher than other fluids at its operating temperatures. Exergy performance of air up to about $310^{\circ} \mathrm{C}$ is higher than other working fluids. However, at temperatures above $310^{\circ} \mathrm{C}$, the maximum exergy of the molten salt increases to $41.19 \%$ at $422{ }^{\circ} \mathrm{C}$.

\section{References}

1. Y. Wang, J. Xu, Q. Liu, Y. Chen, H. Liu, Performance analysis of a parabolic trough solar collector using Al2O3/synthetic oil nanofluid, Applied Thermal Engineering (2016)

2. E. Z. Moya, Innovative working fluids for parabolic trough collectors, CIEMAT, Plataforma Solar de Almería Tabernas (Almería), Spain (2017)

3. M. Biencinto, L. González, E. Zarza, L. E. Díez, J. Muñoz and J. M. Val, Modeling And Simulation of A Loop of Parabolic Troughs Using Nitrogen As Workıng Fluid, Solarpaces (2012)

4. C. Chang, A. Sciacovelli, Z. Wu, Xin Li, Y Li, M. Zhao, J Deng, Z. Wang, Y. Ding, Enhanced heat transfer in a parabolic trough solar receiver by inserting rods and using molten salt as heat transfer fluid, Applied Energy, 220, 337-350 (2018) 
5. A. Bonk, S. Sau, N. Uranga, M. Hernaiz, Thomas Bauer, Advanced heat transfer fluids for direct molten salt line-focusing CSP plants, Progress in Energy and Combustion Science, 67, 69-87, (2018)

6. S. E. Trabelsi, L. Qoaider, A. Guizani, Investigation of using molten salt as heat transfer fluid for dry cooled solar parabolic trough power plants under desert conditions, Energy Conversion and Management, 156 , 253-263 (2018)

7. E. Bellos, C. Tzivanidis, K. A. Antonopoulos, A detailed working fluid investigation for solar parabolic trough collectors, Applied Thermal Engineering, (2016).

8. A. Mwesigye, J. P. Meyer, Optimal thermal and thermodynamic performance of a solar parabolic trough receiver with different nanofluids and at different concentration ratios, Applied Energy, 193, 393-413 (2017)

9. E. Kaloudis, E. Papanicolaou, V. Belessiotis, Numerical simulations of a parabolic trough solar collector with nanofluid using a twophase model, Renewable Energy, 97, 218229 (2016)

10. E. G. Roubaud, D. P. Osorio, C. Prieto, Review of commercial thermal energy storage in concentrated solar power plants: Steam vs. molten salts, Renewable and Sustainable Energy Reviews, 80, 133-148 (2017)

11. https://www.dow.com/

12. Y. Wang, Q. Liu , J. Lei, H. Jin, A threedimensional simulation of a parabolic trough solar collector system using molten salt as heat transfer fluid, Applied Thermal Engineering, 70, 462-476 (2014)

13. T. Bauer, N. Pfleger, N. Breidenbach, M. Eck, D. Laing, S. Kaesche, Material aspects of Solar Salt for sensible heat storage, Applied Energy, 111, 1114-1119 (2013)

14. J. M. Anton, M. Biencinto, E. Zarza, L.E. Díez, Theoretical basis and experimental facility for parabolic trough collectors at high temperature using gas as heat transfer fluid, Applied Energy, 135, 373-381 (2014)

15. K. Kadoya, N. Matsunaga, A. Nagashima, Viscosity and Thermal Conductivity of Dry Air in the Gaseous Phase, Journal of Physical and Chemical Reference Data, 14, 947 (1985)

16. E. W. Lemmon, R. T Jacobsen, Steven G. Penoncello, D. G. Friend, Thermodynamic Properties of Air and Mixtures of Nitrogen, Argon, and Oxygen From 60 to $2000 \mathrm{~K}$ at
Pressures to 2000 Mpa, J. Phys. Chem. Ref. Data, 29, (2000)

17. E. Bellos, C. Tzivanidis, A detailed exergetic analysis of parabolic trough collectors, Energy Conversion and Management, 149, 275-292 (2017)

18. O. Behar, A. Khellaf, K. Mohammedi, A novel parabolic trough solar collector model - Validation with experimental data and comparison to Engineering Equation Solver (EES), Energy Conversion and Management, 106, 268-281 (2015)

19. R. Forristall, Heat Transfer Analysis and Modeling of a Parabolic Trough Solar Receiver Implemented in Engineering Equation Solver, National Renewable Energy Laboratory, (2003)

20. J. A. Duffie, W. A. Beckman, Solar Engineering of Thermal Processes, John Wiley and Sons, (2013)

21. S. A. Kalogirou, A detailed thermal model of a parabolic trough collector receiver, Energy, 48, 298-306, (2012)

22. G. Coccia, G. D. Nicola, A. Hidalgo, Parabolic Trough Collector Prototypes for Low-Temperature Process Heat, Springer, (2016)

23. A. Hepbasli, A key review on exergetic analysis and assessment of renewable energy resources for a sustainable future, Renewable and Sustainable Energy Reviews, 12, 593661 (2008)

24. A. Suzuki, General theory of exergy-balance analysis and application to solar collectors, Energy, 13,153-160, (1988)

25. V. Madadi, T. Tavakoli, A. Rahimi, First and second thermodynamic law analyses applied to a solar dish collector, Non-Equilib. Thermodyn., 39 (4), 183-197 (2014)

26. M. Chafie, M. F. Ben Aissa, A. Guizani, Energetic end exergetic performance of a parabolic trough collector receiver: An experimental study, Journal of Cleaner Production, (2017)

27. R. Loni, E. Askari Asli-ardeh, B. Ghobadian, A.B. Kasaeian, S. Gorjian, Thermodynamic Analysis of a Solar Dish Receiver using Different Nanofluids, Energy, (2017)

28. https://www.loikitsdistribution.com/

29. V. Dudley, G. Kolb, M. Sloan, D. Kearney, SEGS LS2 solar collector-test results, Report of Sandia National Laboratories, SAN941884, (1994) 


\section{Nomenclature}

cp specific heat capacity $\left(\mathrm{J} / \mathrm{kg}^{\circ} \mathrm{C}\right)$

Greek symbols

D diameter $(\mathrm{m})$

Ex exergy $(\mathrm{W})$

f flow friction factor (-)

$\mathrm{h}$ convection heat transfer coefficient $\left(\mathrm{W} / \mathrm{m}^{2}{ }^{\circ} \mathrm{C}\right)$

$\alpha \quad$ absorbance (-)

$\Delta \mathrm{P} \quad$ pressure drop $(\mathrm{Pa})$

$\mathrm{I}_{\mathrm{b}} \quad$ direct normal irradiance $\left(\mathrm{W} / \mathrm{m}^{2}\right)$

$\varepsilon \quad$ emissivity (-)

$\eta \quad$ efficiency (-)

$\mathrm{k}$ thermal conductivity $\left(\mathrm{W} / \mathrm{m}^{\circ} \mathrm{C}\right)$

$\mathrm{K}$ incident angle modifier (-)

L lenght (m)

m mass flow rate $(\mathrm{kg} / \mathrm{s})$

$\gamma \quad$ intercept factor $(-)$

$\theta \quad$ incident angle $\left({ }^{\circ}\right)$

$\mu \quad$ dynamic viscosity (Pa s)

$\rho \quad$ density $(\mathrm{kg} / \mathrm{m} 3)$

$\mathrm{Nu} \quad$ Nusselt number (-)

$\sigma \quad$ Stefan Boltzmann constant $\left(5.67 \times 108 \mathrm{~W} / \mathrm{m}^{2} \mathrm{~K}^{4}\right)$

Pr Prandtl number (-)

Re Reynolds number (-)

$\mathrm{T}$ Temperature $(\mathrm{K})$

u velocity $(\mathrm{m} / \mathrm{s})$

$\mathrm{U}_{\mathrm{L}} \quad$ overall heat transfer coefficient $\left(\mathrm{W} / \mathrm{m}^{2}{ }^{\circ} \mathrm{C}^{2}\right)$

Q heat flux (W)

W Width (m)

\section{Subscripts}

a aparture

abs absorptance

c cover

ci cover inside

co cover outside

col collector

ex exergy

f fluid

opt optical

$\mathrm{p} \quad$ pipe

pi inside of pipe

po outside of pipe

$\mathrm{s}$ sun

th thermal 